\title{
Happiness Through Vacationing: Just a Temporary Boost or Long-Term Benefits?
}

\author{
Jeroen Nawijn
}

Published online: 22 September 2010

(C) The Author(s) 2010. This article is published with open access at Springerlink.com

\begin{abstract}
Does vacationing add to our happiness in the long run? This question was addressed in a study of 3,650 Dutch citizens who reported their leisure travel every 3 months during 2 years and rated their happiness at the end of each year. Participants who had been on vacation appeared to be marginally happier, in terms of hedonic level of affect, than those who had not. This difference in Affect balance between vacationers and non-vacationers is probably due to a very minor causal effect of vacationing on hedonic level of affect. Possibly, vacationing is positively reminisced and these memories allow for the prevalence of more positive affect in people's lives. Happiness did not predict vacationing. The effect of holiday trips on vacationers' happiness is mostly short-lived; among vacationers, happiness was unrelated to the number of trips and days spent on vacation. A separate analysis of vacationers, who value vacationing most, yielded the same results. Implications for future research are discussed.
\end{abstract}

Keywords Affect · Holiday trips · Longitudinal · Subjective well-being · Tourism

\section{Introduction}

\subsection{Happiness}

Happiness is a highly valued matter, with a few exceptions all humans want to be happy and many people try to get happier than they are. Generally speaking, individuals control only approximately $40 \%$ of their happiness. Some $50 \%$ of the differences among people's

J. Nawijn (凹)

Academy for Tourism, Centre for Sustainable Tourism and Transport, NHTV Breda University of Applied Sciences, Mgr. Hopmansstraat 1, P.O. Box 3917, 4800 DX Breda, The Netherlands e-mail: nawijn.j@nhtv.nl

J. Nawijn

Faculty of Social Sciences, World Database of Happiness, Erasmus University Rotterdam, Rotterdam, The Netherlands 
happiness levels are accounted for by their genetically determined set points, while $10 \%$ is accounted for by unintentional activity (Lyubomirksy et al. 2005).

Individuals can improve their happiness by changing their actions (Sheldon and Lyubomirksy 2006). People can invest time in (social) relationships (Diener and Seligman 2002) or actively participate in positive psychological programs such as life-coaching (Green et al. 2006), using signature strengths (Seligman et al. 2005) or mindfulness (Brown and Ryan 2003). Furthermore, individuals can try to change their state of mind, through cultivating optimism (Seligman 1990) or avoiding social comparisons (Lyubomirksy 2008; Swinyard et al. 2001).

Activities in general (Csikszentmihalyi and Hunter 2003; Csikszentmihalyi and Wong 1991; Kelly et al. 1987), and specific activities, such as active participation in sports (Hills and Argyle 1998) or music (Laukka 2007), tend to increase happiness. The leisure domain seems to be an appropriate domain to improve one's sense of well-being (Ateca-Amestoy et al. 2008; Spiers and Walker 2009).

\subsection{Tourism}

Modern-day society pushes individuals to consume and work more (Easterbrook 2003; Schor 1991, 1998). Because of this, we have become increasingly demanding of our leisure time. The activities we undertake in our free time are an important escape from work, making the leisure domain a setting in which to relax and de-stress. More so, individuals have the need to enjoy rather mundane activities, such as grocery shopping; even ordinary activities seem to be turned into 'experiences' (Pine and Gilmore 1999). Less frequently enjoyed experiences, such as holiday experiences, are becoming more and more accessible to people worldwide; trip frequency has been rising for years (Opperman 1995) and tourist arrivals are also expected to rise further over the next decade (UNWTO 2008).

The tourism industry lets us believe that vacationing makes us happier. Advertisements depict smiling faces, sunny beaches and people having a good time. The question is whether this is really true. Do we actually become happier by going on holiday? Vacationing may be just another focusing illusion, in the sense that we think we become happier by going on holiday, while in reality we do not become any happier than we were before (Kahneman et al. 2006).

Tourism experiences may add to individuals' happiness in two ways. First, through direct effects of the holiday trip itself, wherein three phases can be distinguished: (1) pretrip (through anticipation), inter-trip (through experience) and post-trip (through afterglow). Second, tourism experiences may contribute to happiness in everyday life through more indirect mechanisms, such as reminiscing of holiday experiences through memories (Larsen 2007; Morgan and Xu 2009), enforced by physical objects such as photographs and souvenirs, mental storage through affections, impressions and new meanings, and enrichment through social networks (Aho 2001). Also, holidays may strengthen family bonds which in turn could increase satisfaction with family life. Recent research has shown that positive and negative affect generated from trip experiences is associated with satisfaction from several life domains, such as love life, family life and social life (Sirgy et al. 2010).

\subsection{Earlier Research on Tourism and Happiness}

Several cross-sectional studies have found small, but positive, associations between a holiday trip and happiness (Kemp et al. 2008; Neal 2000). Others found (positive) 
associations between certain aspects of a holiday trip and happiness (Milman 1998). For instance, vacationers who participate in many trip-related activities are happier than vacationers who undertake fewer activities (Milman 1998).

Individuals savor (Bryant and Veroff 2007) holidays through anticipating forthcoming trips. Those anticipating a trip are happier than those not anticipating a trip (Hagger and Murray 2009). People enjoy having something to look forward to, and holidays are typically something that people look forward to. For this reason, it is argued that people tend to prefer short breaks over longer holidays (Miller et al. 2007); this would allow them more trips to look forward to during the year. However, most studies find no association between length of stay and post-trip happiness (Gilbert and Abdullah 2004; Kemp et al. 2008; Lounsbury and Hoopes 1986). Only Neal and Sirgy (2004) found a moderating effect of length of stay between holiday satisfaction and happiness. Furthermore, not everyone enjoys the anticipation of a holiday trip. For some, anticipating a holiday evokes feelings of homesickness (Vingerhoets et al. 1997) and stress, especially for those who have difficulty to let go of their everyday routines (Vingerhoets et al. 2002).

Holiday satisfaction may lead to higher post-trip happiness levels; satisfaction with a holiday is positively associated with post-trip happiness (Lounsbury and Hoopes 1986; Westman and Eden 1997). A number of pre-test/post-test design studies have found higher levels of happiness (Gilbert and Abdullah 2004; Nawijn et al. 2010) and other positive effects, such as decreased levels of stress and generally better health, after a holiday trip (Strauss-Blasche et al. 2000; Westman and Eden 1997; Westman and Etzion 2001), although these effects fade out rather quickly (De Bloom et al. 2009).

Thus, holidays boost pre-trip happiness through anticipation and post-trip happiness through afterglow effects. Whether there is a selection effect, in the sense that happy individuals take more holiday trips, is unknown; this may be the case as there is evidence suggesting that vacationers are generally happier than non-vacationers (Gilbert and Abdullah 2004; Nawijn et al. 2010). In addition, holiday trips are reminisced and savored long after the holiday took place. Holiday trips may boost happiness in the long run as more trips or more vacation days per year could be associated with higher happiness, as happiness is about the frequency of positive affect, not the intensity (Diener et al. 1990). However, as far as the author is aware, no study on the long-term effects of vacationing on happiness exists.

\subsection{Questions}

This paper adds to the current literature on holiday trips and subjective well-being by seeking an answer to the following questions: (1) Are vacationers happier than nonvacationers? (2) Do vacationers become happier if they take more trips and less happy with less trips? (3) Does vacationing add to everyone's happiness or only to the happiness of people who value vacationing?

\section{Method}

\subsection{Respondents}

This study makes use of data from the GfK Leisure and Tourism panel, which were made available to the author by GfK Panel Services. This panel is representative of the Dutchspeaking population. Panel members fill in questionnaires four times per year, reporting 
detailed accounts of their leisure travel. This study makes use of the 2007 and 2008 travel data and the assessment of panel members' subjective well-being, which took place for the first time in December 2007 and was followed-up by a second measurement in December 2008. The original 2007 sample consisted of an initial 5,700 respondents.

The second measurement of happiness, which took place at the end of 2008, was conducted only among the vacationers of 2008. Furthermore, individuals who were within a month of departure or return date were excluded from the sample, as otherwise anticipation or afterglow effects would interfere. Therefore, the final sample was smaller than the initial sample and consists of approximately 3,650 individuals, 33\% of which are men. Since women are overrepresented in the sample, all analyses are weighed for sex, creating a 50/50 division of men and women. Mean age is $45(\mathrm{SD}=15)$ and modal monthly net household income is €2,200. Most have a paid job (59\%), or are retired (13\%). The majority holds a high school degree $(35 \%)$ or a graduate or undergraduate degree $(35 \%)$.

\subsection{Variables}

\subsubsection{Happiness}

Following Veenhoven (1984), happiness is defined as 'the overall appreciation of one's life as a whole'. Another word for this matter is 'life-satisfaction'. Veenhoven assumes that the overall appraisal of life draws on two sources of information: how well we feel generally and how well life fits our wants. He refers to these sub-appraisals as 'components' of happiness, the affective component is termed hedonic level and the cognitive component is referred to as contentment. The dataset used in the present study includes measures of both life-satisfaction and hedonic level, but not of contentment.

2.2.1.1 Life-satisfaction Overall appreciation of life is measured using reported agreement to the statement: "I am satisfied with my life". The responses to this statement were measured on a 5-point scale, with responses ranging from "totally disagree" to "totally agree". Mean life-satisfaction in 2007 was 3.87 (SD = .78) and 3.97 in 2008 (SD = .76).

2.2.1.2 Hedonic level How well people feel can be measured using an Affect balance scale, such as the PANAS (Watson et al. 1988) or the ABS (Bradburn 1969). The Affect balance used in the current study is derived from responses to six questions about how one generally felt and consisted of three positively formulated items and three negative ones. The positive items were 'enthusiastic', 'free, loose, relaxed' and 'cheerful'; the negative items were 'depressed', 'tense' and 'impatient'. The responses were measured on a 5-point scale, with the following response alternatives: "never", "seldom", "sometimes", "often" and "constantly". Affect balance is the degree to which positive experiences outweigh negative ones and is computed by subtracting the sum of the negative scores from the sum of the positive scores. The possible range of the resulting scale is -12 (average positive 3 , negative 15) to +12 (average positive 15, negative 3 ). The mean score of the Affect balance in 2007 was $3.78(\mathrm{SD}=3.05)$ and $3.51(\mathrm{SD}=3.13)$ in 2008.

\subsubsection{Vacationing}

The frequency of holiday trips in 2007 and 2008 was measured in numbers. A holiday trip was considered a trip where one was "traveling to and staying in places outside their usual 
environment for more than one night, but not more than one consecutive year, for leisure purposes' (UNWTO 1995). The mean number of trips over 2007 and 2008 was 2.21 ( $\mathrm{SD}=1.47$ ), with the majority taking up to 3 trips. The maximum number of trips was 17 .

The number of vacation days of 2007 and 2008 were also assessed. The mean number of days spent on holiday was $29.50(\mathrm{SD}=19.99)$.

\subsubsection{Importance of Vacationing}

Respondents indicated the importance of vacationing for them as an individual as "not important", "neutral" or "important". $31 \%$ of the sample considered vacationing unimportant, $29 \%$ were neutral and $40 \%$ considered vacationing important.

\subsubsection{Socio-Demographic Variables}

Educational level, net household income, employment status, age and sex were all assessed.

\subsection{Analysis}

The data analysis is both cross sectional as well as longitudinal. The cross-sectional analyses focus on assessing happiness differences between vacationers and non-vacationers and are used to assess whether happiness at the end of the year is related to vacationing earlier in that year. The longitudinal analyses focus on whether a change in vacationing is followed by similar change in happiness and whether happiness predicts vacationing.

\section{Results}

\subsection{Are Vacationers Happier Than Non-Vacationers?}

To test whether vacationers are generally happier than non-vacationers, the scores on the Affect balance and the life-satisfaction question in 2007 were compared to the travel data of 2007, by means of two-one way analyses of covariance. The independent variable indicated whether the respondent had at least one holiday trip in 2007, or none at all. As covariates, the continuous socio-demographics were used. Preliminary assumption testing was conducted to check for normality, linearity, univariate and multivariate outliers, homogeneity of variance-covariance matrices, and multicollinearity, with no serious violations noted. As seen in Fig. 2, vacationers had a slightly higher score on the Affect balance $(M=4.12, \mathrm{SD}=3.03, n=2,057)$ than non-vacationers $(M=3.66, \mathrm{SD}=2.88$, $n=988)$ and this difference was statistically significant, $F(1,3,040)=12.79, p<.001$. The effect size, as indicated by a partial eta squared of .004, is small. Life-satisfaction scores were also slightly higher among vacationers $(M=3.87, \mathrm{SD}=.79, n=2,057)$ than they were among non-vacationers $(M=3.83, \mathrm{SD}=.84, n=988)$, which was not a significant difference, $F(1,3,040)=.45, p=$ ns (see Fig. 1). Thus, people who had a holiday trip in the last year are marginally happier than those who had not.

The question is whether this marginal difference is causal. To test the possible causality three methods were used. First, the partial correlations were calculated. The 2008 partial correlations were controlled for the happiness measures of 2007, which was a first attempt 
Fig. 1 Vacationers and nonvacationers' life-satisfaction

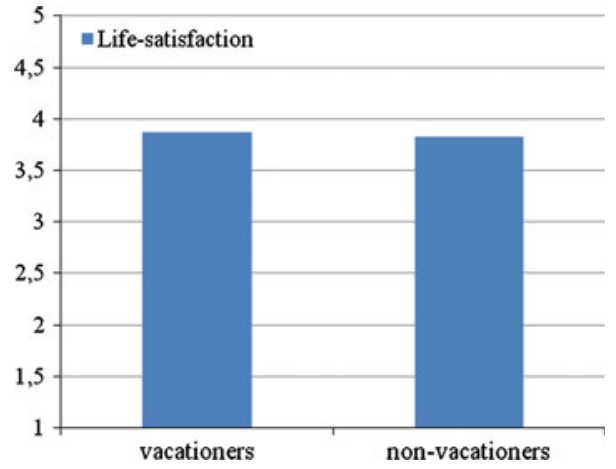

Fig. 2 Vacationers and nonvacationers' Affect balance

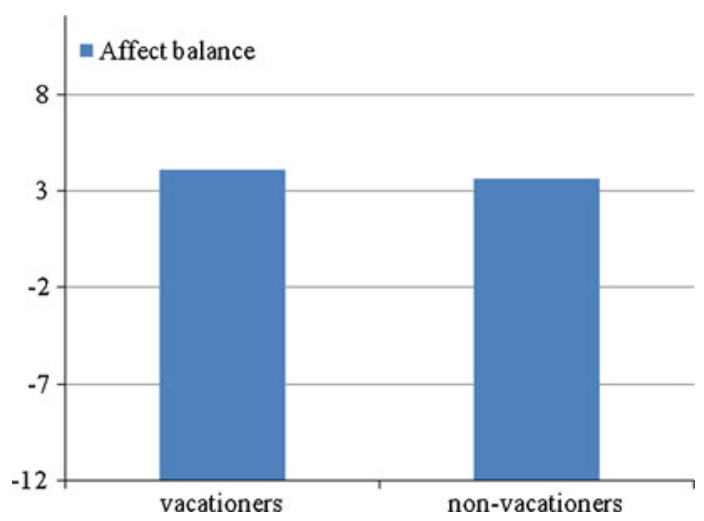

to assess the possible cause/effect relation. And, adding to that analysis, I assessed whether the non-vacationers of 2007 increased their happiness by vacationing in 2008. Next, I tested if happiness predicted vacationing (in number of days and number of trips). Finally, it was assessed whether a change in trip frequency or number of vacation days affected happiness.

\subsection{Do Vacationers Become Happier if They Take More Trips and Less Happy with Less Trips?}

To test whether the frequency of holiday trips was associated with happiness, partial correlations were performed between the 2007 and 2008 happiness scores and their corresponding trip frequencies/number of days spent on vacation. The continuous sociodemographical variables were used as covariates. The 2008 scores were also controlled for the happiness scores of 2007. All associations (as displayed in Table 1) were not significant.

Next, the analyses focused on the differences in happiness between 2007 and 2008. As mentioned under 'method', the 2008 data contained only vacationers. Therefore, it was possible to distinguish two groups: those who were non-vacationers in 2007 and became vacationers in 2008, and those who were vacationers in both 2007 and 2008. For these two groups the mean happiness scores were compared and it was tested whether these mean scores differed significantly. The outcome is presented in Table 2. 
Table 1 Partial correlations of vacationing and happiness

\begin{tabular}{lllllll}
\hline Year & Happiness & Number of trips & $n$ & Number of days & $n$ & Sig. \\
\hline \multirow{2}{2007}{} & Affect balance & $r=+.01$ & 2,957 & $r=+.01$ & 2,377 & $\mathrm{~ns}$ \\
& Life-satisfaction & $r=+.01$ & 2,957 & $r=.00$ & 2,377 & $\mathrm{~ns}$ \\
\multirow{2}{*}{2008} & Affect balance & $r=+.02$ & 2,955 & $r=-.02$ & 2,955 & $\mathrm{~ns}$ \\
& Life-satisfaction & $r=+.02$ & 2,955 & $r=.00$ & 2,955 & $\mathrm{~ns}$ \\
\hline
\end{tabular}

Table 2 Mean happiness differences 2007-2008

\begin{tabular}{lllllll}
\hline Had a vacation in the year & Happiness & $M(2007)$ & $M(2008)$ & $t$ & $d f$ & Sig. \\
\hline \multirow{2}{*}{2008 only } & Affect balance & 3.64 & 3.51 & +0.93 & 1,033 & ns \\
\multirow{2}{*}{2007 and 2008} & Life-satisfaction & 3.85 & 3.96 & -3.30 & 1,033 & .01 \\
& Affect balance & 3.86 & 3.52 & +3.96 & 2,620 & .001 \\
& Life-satisfaction & 3.88 & 3.98 & -4.73 & 2,620 & .001 \\
\hline
\end{tabular}

As can be seen in Table 2, vacationers' life-satisfaction increased significantly, but their Affect balance decreased significantly. Non-vacationers' life-satisfaction also increased significantly and their Affect balance decreased as well, but not significantly.

\subsection{Does Happiness Predict Vacationing?}

People who had a vacation in the last year are slightly happier than those who had not. Is that because the trip(s) had made them happier, or were they happier to begin with and their happiness made them more willing to take a trip? Since vacationers' life-satisfaction scores were significantly higher than non-vacationers' life-satisfaction scores, it was assessed whether life-satisfaction in 2007 predicted trip frequency in 2008. Again, the correlations were controlled for the socio-demographics. Life-satisfaction scores did not 'predict' future trip frequency. Pearson correlation indicated zero as a value $(n=2,957)$. Although no differences were observed between vacationers' and non-vacationers affect scores, a partial correlation between trip frequency and the Affect balance was also calculated. The results were exactly the same as those for life-satisfaction $(r=.00, p=\mathrm{ns}$, $n=2,957)$. Similarly, the Affect balance $(r=+.01, p=\mathrm{ns}, n=2,448)$ and life-satisfaction of 2007 ( $r=.00, p=\mathrm{ns}, n=2,448)$ did not predict number of days spent on holiday in 2008 .

\subsection{Does a Change in Trip Frequency Affect Happiness?}

To answer the question whether vacationing has an effect in the long run, it was assessed how a change in trip frequency from 2007 to 2008 affected happiness scores at the end of 2008. The underlying assumption was that an increase in trips (e.g., going from two trips in 2007 to four trips in 2008) would positively affect happiness scores, and that the opposite effect would take place when a decrease in trip frequency had occurred. The earlier happiness measurements and socio-demographics were used as covariates. The associations between the changes in trip frequency and days spent on vacation and the Affect balance scores are displayed in Figs. 3 and 4. 


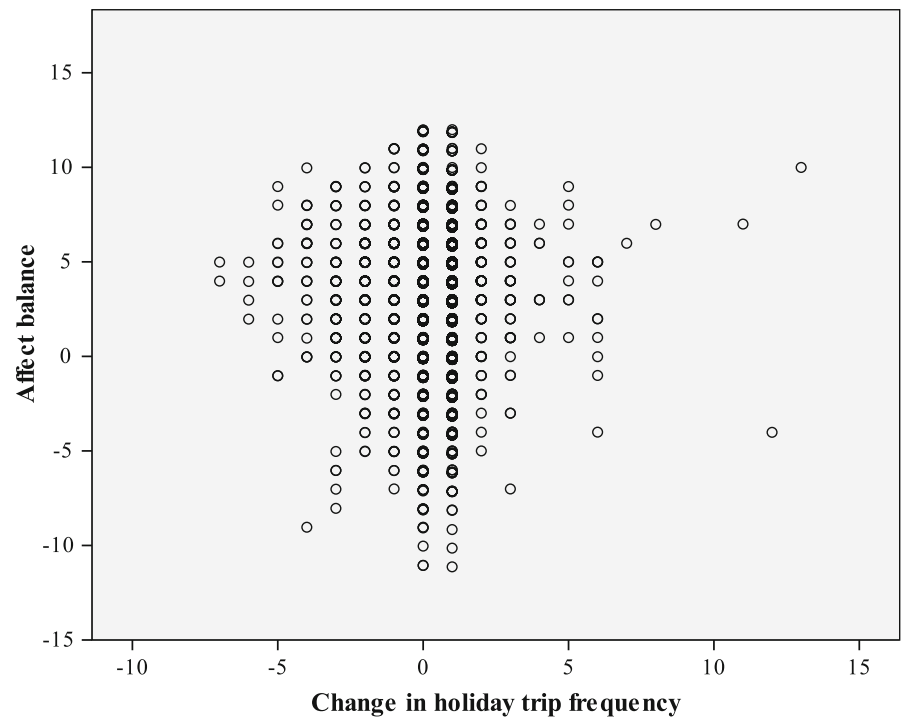

Fig. 3 The Affect balance and a change in trip frequency

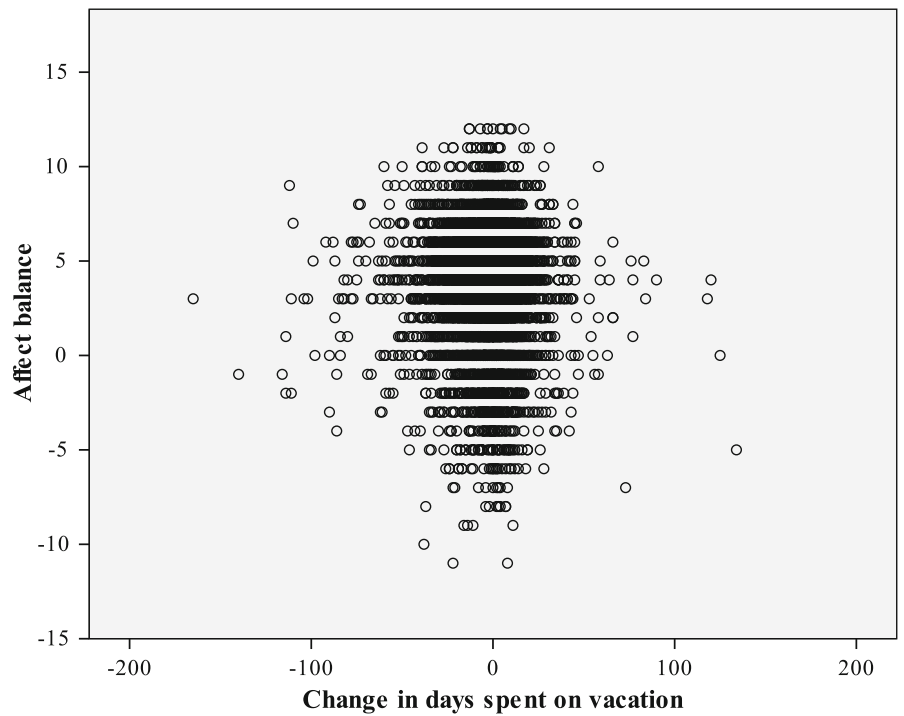

Fig. 4 The Affect balance and a change in days spent on vacation

No significant associations were observed between a change in trip frequency and the Affect balance $(r=+.02, p=\mathrm{ns}, n=2,059)$ and in the same way, life-satisfaction was not associated with a change in trip frequency either $(r=+.03, p=\mathrm{ns}, n=2,059)$. Similarly, a change in the number of days spent on holiday between 2007 and 2008 was neither associated with the Affect balance $(r=.00, p=\mathrm{ns}, n=2,060)$ nor life-satisfaction $(r=-.01, p=\mathrm{ns}, n=2,060)$. 
3.5 Does Vacationing Add to the Happiness of People Who Value Vacationing?

The previous analysis showed that a change in trip frequency or a change in vacation days did not influence happiness. A possible explanation is that the findings were blurred by a group of respondents who did not consider vacationing important. If one does not care for vacationing, it is unlikely that it would affect one's happiness. Thus finally, it was assessed whether those who value vacationing would benefit from vacationing, more so than those who do not value vacationing. Again, socio-demographical variables were used as covariates.

The Affect balance and life-satisfaction were both not significantly associated with trip frequency or the number of vacation days. A change in trip frequency $(r=+.02, p=\mathrm{ns}$, $n=823)$ or a change in number of days spent on vacation $(r=+.02, p=n s, n=823)$ was not associated with life-satisfaction either. Furthermore, the Affect balance was also not significantly associated with a change in number of days spent on holiday $(r=+.02$, $p=\mathrm{ns}, n=823)$, nor with a change in trip frequency $(r=+.03, p=\mathrm{ns}, n=823)$.

Finally, to test whether mean happiness had significantly increased or decreased from 2007 to 2008 several $t$-tests were performed; using the same groups as presented earlier in Table 2, but this time these groups were split by whether they deemed vacationing important or not.

Logically, non-vacationers of 2007 who became vacationers in 2008 were expected to have the strongest increase in happiness. This was not the case. Although that particular group increased their life-satisfaction significantly (a +.12 increase; from 3.85 to 3.97 ), this was not any different from vacationers of 2007, who valued vacationing and were also vacationers in 2008 ( +.13 increase). Even the non-vacationers who did not value vacationing increased their life-satisfaction by +.10 , albeit not significantly. The Affect balance decreased for all groups, except for the non-vacationers who valued vacationing $(+.02$ increase, not significant). However, the only significant decrease in Affect balance was for the vacationers who did not value vacationing (Table 3).

\section{Discussion}

\subsection{Vacationers Hardly Happier}

This study demonstrated that individuals who vacationed in the last year are marginally happier, in terms of affect balance, than those who did not go on a holiday trip all year. The

Table 3 Mean happiness differences split by importance of vacationing

\begin{tabular}{llllllll}
\hline Had a vacation in the year & Important & Happiness & $M(2007)$ & $M(2008)$ & $t$ & $d f$ & Sig. \\
\hline 2008 only & \multirow{2}{*}{ Yes } & Affect balance & 3.71 & 3.73 & -0.07 & 388 & $\mathrm{~ns}$ \\
& & Life-satisfaction & 3.85 & 3.97 & -2.21 & 388 & .05 \\
& \multirow{2}{*}{ No } & Affect balance & 3.64 & 3.31 & +1.34 & 300 & $\mathrm{~ns}$ \\
& \multirow{2}{*}{ Yes } & Life-satisfaction & 3.87 & 3.97 & -1.43 & 300 & $\mathrm{~ns}$ \\
& & Affect balance & 3.89 & 3.57 & +1.93 & 717 & $\mathrm{~ns}$ \\
& \multirow{2}{*}{ No } & Life-satisfaction & 3.87 & 4.00 & -3.10 & 717 & .005 \\
& & Affect balance & 3.90 & 3.52 & +2.07 & 534 & .05 \\
& & Life-satisfaction & 3.93 & 3.96 & -0.55 & 534 & $\mathrm{~ns}$ \\
\hline
\end{tabular}


Affect balance decreased from 2007 to 2008, possibly due to an exogenous variable, but the 2007 non-vacationers, who all vacationed in 2008, did not significantly decrease their hedonic level of affect. Furthermore, the non-vacationers who valued vacationing even increased their affect balance mildly, although not significantly. This further supports the assumption that the difference in affect balance between vacationers and non-vacationers is probably due to a very minor causal effect of vacationing on hedonic level of affect.

In terms of life-satisfaction, vacationers are not significantly different from non-vacationers. This partly confirms findings by Gilbert and Abdullah (2004), who found that vacationers are generally happier, in terms of both affect, as well as life-satisfaction. The reason for the slightly different findings of the current study may be due to the fact that Gilbert and Abdullah did not exclude the anticipation and afterglow phases from their analyses.

\subsection{Trip Frequency Does Not Matter}

The current study also demonstrated that more trips are not necessarily better for happiness. Although vacationers are slightly happier-in terms of affect-compared to non-vacationers, individuals who increased their trip frequency, or number of days spent on holiday, from 2007 to 2008, or reduced the number of trips and/or days, did not significantly change their happiness. This even applied to those who valued vacationing.

Furthermore, happiness did not predict the frequency of holiday trips in the subsequent year either. In that sense, this study did not find a selection effect; happier people do not take more holiday trips.

Thus, vacationers' happiness does not increase their sense of well-being in the long run. The effect of holiday trips on vacationers' happiness is only short-lived. Anticipation boosts vacationers' pre-trip happiness (Gilbert and Abdullah 2002; Hagger and Murray 2009); inter-trip, vacationers are generally in good spirits (De Bloom et al. 2010; Nawijn 2010) and they benefit afterwards, if their holiday was stress-free (Nawijn et al. 2010). However, these positive effects do not last for long and do not have a sustained effect on vacationers' general happiness.

\subsection{Explanation of the Findings}

Vacationing has a very small positive effect on hedonic level of affect. A possible explanation of this finding is that vacationing is positively reminisced and these memories allow for the prevalence of more positive affect in people's lives. Additionally, a spillover effect of holiday travel may be present. Affect related to vacationing may add to affect in different life domains, which consequently influences general Affect balance (Sirgy et al. 2010).

However, hedonic level of affect does not increase more by taking more trips. A possible reason for the absence of such an effect of vacationing on happiness is that tourism experiences are not considered 'special' any more. In Western societies, tourism has become a much more integral part of life (Larsen 2008; McCabe 2002) and experiences that were once confined to tourism are now accessible in everyday life (Lash and Urry 1994).

The finding that vacationing-in terms of frequency of trips and number of days on holiday-is not significantly associated with life-satisfaction or hedonic level of affect, coincides well with homeostatic set-point theory, which argues that happiness is a rather stable 'trait' (Cummins 2005). Set-point theory holds that, whatever we do, we cannot change our happiness much. In this view, particular experiences, such as holiday trips, can 
at best provide a temporary uplift, after which we return to our set-point. Yet set-point theory does not account for enduring changes in happiness following major changes in life such as unemployment and widowhood (e.g., Headey 2006; Veenhoven 1994) and in that context the interpretation should rather be that a few vacation days or trips more or less is too trivial to affect happiness.

The effect of vacationing on contentment was not assessed in the current study. Possibly, vacationing has a small negative long-term effect on contentment, which would explain the absence of a long-term effect of vacationing on life-satisfaction. A reason for this potential small negative effect could be that vacationers compare their everyday lives to their holiday experience, a period when they are generally very happy (De Bloom et al. 2010; Nawijn 2010). Such a comparison may lower vacationers' contentment with their everyday lives.

\subsection{Implications}

The positive effects which vacationing has on happiness are mostly limited to the duration of the holiday trip itself (De Bloom et al. 2010; Nawijn 2010) and a brief phase of anticipation (Nawijn et al. 2010) and afterglow (De Bloom et al. 2009; Nawijn et al. 2010). It seems fair to say that holiday trips offer mostly an uplift in mood and the kind of satisfaction which Veenhoven (2010) would regard as a pleasure, a passing kind of satisfaction related to a part of life. If one wants to boost their happiness by means of vacationing, one has to take many holidays, in order to enjoy many short-lived periods of increased happiness.

This conclusion is not necessarily bad news for the tourism industry. In fact, it is probably good news, as this means that people are best off by booking many trips and consequently experiencing many brief happiness boosts.

\subsection{Limitations}

A limitation of the current study-but a rather obvious one-is that it was not possible to restrict or expand travel for certain individuals. Offering people free trips or paying people not to take a vacation may have resulted in different findings as there are signs that restricting travel would affect tourists' happiness (Nawijn and Peeters 2010). However, an objection to such experiments is that these are costly and involve loss of self-control, which is important to happiness (Eriksson et al. 2007; Larson 1989). Some ethical issues might arise also.

Furthermore, the extent to which respondents anticipate or reminisce tourism experiences was not assessed. It is possible that those who anticipate or reminisce such experiences more than others, benefit more in terms of happiness.

Additionally, we have to keep in mind that this study drew on a sample of Dutch citizens. The Dutch are generally well-traveled and perhaps this has led to a certain amount of adaptation or routine (Bargeman and Van Der Poel 2006). It is plausible that individuals from other, poorer and less well-traveled, nations may benefit differently from vacationing in terms of happiness.

\subsection{Future Research}

Although the long-term effect of vacationing on happiness is limited, it may have a more profound effect, in a positive or negative manner, on the happiness of locals living and/or 
working in holiday destinations. Studies on the effects of tourism on the local population have focused mostly on economic effects (Hall 2007), but should also include subjective criteria, such as happiness. Up to date, only a single study on locals' happiness has been performed (Becchetti et al. 2009). That particular study focused on Peruvian fair trade producers and found that producers from the poor area benefited more from taking part in the development program, in terms of happiness, compared to the relatively more affluent area.

Also, it would be particularly interesting to apply a different research method and assess whether people who cannot afford a holiday, and are paid to take one through social tourism projects (McCabe 2009), benefit from such a vacation, in the long run, in terms of happiness.

Furthermore, following the aforementioned reasoning that tourism experiences are not considered 'special' any more, future research should assess the potential effect vacationing has for individuals from less well-traveled countries.

Along the same line, it is recommended that more studies are undertaken on the meaning of a vacation for individuals. This could be done in both a qualitative or quantitative manner, or a combination of the two. If one were to ask respondents about their most happy experiences in their life, it would not be surprising to see a vacation make it to the top ten list, as a major peak experience.

Bryant and Veroff (2007) and Tugade and Fredrickson (2007) argue that anticipation and/or savoring of a vacation could prolong the duration of positive emotional experiences. More research is needed on whether anticipation and/or savoring of a holiday tripregardless of when it is taking place-affects individuals' sense of well-being.

Additionally, a longer follow-up study will be necessary to further analyze the effects of vacationing on happiness. Vacationing ought to be considered as part of a leisure lifestyle, incorporating various aspects of leisure life, social life, family life and work life.

Finally, future research ought to assess which type of people benefit most from which type of holidays. Certain aspects of holiday trips, or certain types of trips, may be better suited to a certain type of personality (Frew and Shaw 1999). Detailed information on the link between personality, behavior and happiness in a tourism context would enable the tourism industry to develop improved products, which match the needs and wants of their customers to a larger extent. The key is finding the right person-environment fit.

\section{Conclusions}

Vacationing works out positively on happiness. The effect is small and mostly short-lived however; in the year after a trip, vacationers are only marginally happier. Among vacationers, and even among those who value vacationing, happiness was unrelated to the number of trips and days spent on vacation.

Open Access This article is distributed under the terms of the Creative Commons Attribution Noncommercial License which permits any noncommercial use, distribution, and reproduction in any medium, provided the original author(s) and source are credited.

\section{References}

Aho, S. K. (2001). Towards a general theory of touristic experiences: Modelling experience process in tourism. Tourism Review, 56(3/4), 33-37.

Ateca-Amestoy, V., Serrano-del-Rosal, R., \& Vera-Toscano, E. (2008). The leisure experience. The Journal of Socio-Economics, 37(1), 64-78. 
Bargeman, B., \& Van Der Poel, H. (2006). The role of routines in the vacation decision-making process of dutch vacationers. Tourism Management, 27(4), 707-720.

Becchetti, L., Castriota, S., \& Solferino, N. (2009). Development projects and life satisfaction: An impact study on fair trade handicraft producers. Journal of Happiness Studies. doi:10.1007/s1090210009-19179-10909.

Bradburn, N. M. (1969). The structure of psychological well-being. Chicago: Aldine.

Brown, K. W., \& Ryan, R. M. (2003). The benefits of being present: Mindfulness and its role in psychological well-being. Journal of Personality and Social Psychology, 84(4), 822-848.

Bryant, F. B., \& Veroff, J. (2007). Savoring: A new model of positive experience. Mahwah, New Jersey, London: Lawrence Erlbaum Associates, Publishers.

Csikszentmihalyi, M., \& Hunter, J. (2003). Happiness in everyday life: The uses of experience sampling. Journal of Happiness Studies, 4(2), 185-199.

Csikszentmihalyi, M., \& Wong, M. M.-H. (1991). The situational and personals correlates of happiness: A cross-national comparison. In F. Strack, M. Argyle, \& N. Schwarz (Eds.), Subjective well-being: An interdisciplinary perspective (Vol. 21, pp. 193-212). Oxford: Pergamon Press.

Cummins, R. A. (2005). Moving from the quality of life concept to a theory. Journal of Intellectual Disability Research, 49(10), 699-705.

De Bloom, J., Geurts, S. A. E., Taris, T. W., Sonnentag, S., De Weerth, C., \& Kompier, M. A. J. (2010). Effects of vacation from work on health and well-being: Lots of fun, quickly gone. Work \& Stress, 24(2), 196-216.

De Bloom, J., Kompier, M. A. J., Geurts, S. A. E., De Weerth, C., Taris, T., \& Sonnentag, S. (2009). Do we recover from vacation? Meta-analysis of vacation effects on health and well-being. Journal of Occupational Health, 51(1), 13-25.

Diener, E., Sandvik, E., \& Pavot, W. (1990). Happiness is the frequency, not the intensity of positive versus negative affect. In F. Strack, M. Argyle, \& N. Schwarz (Eds.), The social psychology of subjective well-being. Elmsford, NY: Pergamon Press.

Diener, E., \& Seligman, M. (2002). Very happy people. Psychological Science, 13, 81-84.

Easterbrook, G. (2003). The progress paradox: How life gets better while people feel worse (1st ed.). New York: Random House.

Eriksson, L., Rice, J. M., \& Goodin, R. E. (2007). Temporal aspects of life satisfaction. Social Indicators Research, 80(3), 511-533.

Frew, E. A., \& Shaw, R. N. (1999). The relationship between personality, gender, and tourism behavior. Tourism Management, 20(2), 193-202.

Gilbert, D., \& Abdullah, J. (2002). A study on the impact of the expectation of a holiday on an individual's sense of well-being. Journal of Vacation Marketing, 8(4), 352-361.

Gilbert, D., \& Abdullah, J. (2004). Holidaytaking and the sense of well-being. Annals of Tourism Research, 31(1), 103-121.

Green, L. S., Oades, L. G., \& Grant, A. M. (2006). Cognitive-behavioral, solution-focused life coaching: Enhancing goal striving, well-being, and hope. The Journal of Positive Psychology, 1(3), 142-149.

Hagger, J. C., \& Murray, D. (2009). The contribution of multiple cycles of tourism experiences to post retirement life satisfaction: An Australian study. Paper presented at the Tourist Experiences: Meanings, Motivations, Behaviours conference, University of Central Lancashire, Preston, United Kingdom.

Hall, C. M. (2007). Pro-poor tourism: Who benefits? Perspectives on tourism and poverty reduction. Clevedon: Channel View Publications.

Headey, B. (2006). Happiness: Revising set point theory and dynamic equilibrium theory to account for long term change, Discussion Paper 607. Berlin: DIW Berlin German Institute for Economic Research.

Hills, P., \& Argyle, M. (1998). Positive moods derived from leisure and their relationship to happiness and personality. Personality and Individual Differences, 25(3), 523-535.

Kahneman, D., Krueger, A. B., Schkade, D., Schwarz, N., \& Stone, A. A. (2006). Would you be happier if you were richer? A focusing illusion. Science, 312(5782), 1908-1910.

Kelly, J. R., Steinkamp, M. W., \& Kelly, J. R. (1987). Later-life satisfaction: Does leisure contribute? Leisure Sciences, 9(1), 120-189.

Kemp, S., Burt, C. D. B., \& Furneaux, L. (2008). A test of the peak-end rule with extended autobiographical events. Memory \& Cognition, 36(1), 132-138.

Larsen, S. (2007). Aspects of a psychology of the tourist experience. Scandinavian Journal of Hospitality and Tourism, 7(1), 7-18.

Larsen, J. (2008). De-exoticizing tourist travel: Everyday life and sociality on the move. Leisure Studies, 27(1), 21-34.

Larson, R. (1989). Is feeling "In control" related to happiness in daily life? Psychological Reports, 64(3), 775-784. 
Lash, S., \& Urry, J. (1994). Economies of signs and space. London: Sage.

Laukka, P. (2007). Uses of music and psychological well-being among the elderly. Journal of Happiness Studies, 8(2), 215-241.

Lounsbury, J. W., \& Hoopes, L. L. (1986). A vacation from work: Changes in work and nonwork outcomes. Journal of Applied Psychology, 71(3), 392-401.

Lyubomirksy, S. (2008). The how of happiness: A scientific approach to getting the life you want. New York: The Penguin Press.

Lyubomirksy, S., Sheldon, K. M., \& Schkade, D. (2005). Pursuing happiness: The architecture of sustainable change. Review of General Psychology, 9(2), 111-131.

McCabe, S. (2002). The tourist experience and everyday life. In G. M. S. Dann (Ed.), The tourist as a metaphor of the social world (pp. 61-77). Wallingford: CABI.

McCabe, S. (2009). Who needs a holiday? Evaluating social tourism. Annals of Tourism Research, 36(4), 667-688.

Miller, G., Rathouse, K., Scarles, C., Holmes, K., \& Tribe, J. (2007). Public understanding of sustainable leisure and tourism: A report to the department for environment, food and rural affairs. London: Delfra, University of Surrey.

Milman, A. (1998). The impact of tourism and travel experience on senior travelers' psychological wellbeing. Journal of Travel Research, 37(2), 166-170.

Morgan, M., \& Xu, F. (2009). Student travel experiences: Memories and dreams. Journal of Hospitality Marketing \& Management, 18(2), 216-236.

Nawijn, J. (2010). The holiday happiness curve: A preliminary investigation into mood during a holiday abroad. International Journal of Tourism Research, 12(3), 281-290.

Nawijn, J., Marchand, M., Veenhoven, R., \& Vingerhoets, A. (2010). Vacationers happier, but most not happier after a holiday. Applied Research in Quality of Life, 5(1), 35-47.

Nawijn, J., \& Peeters, P. M. (2010). Travelling 'green': Is tourists' happiness at stake? Current Issues in Tourism, 13(4), 381-392.

Neal, J. D. (2000). The effects of different aspects of tourism services on travelers' quality of life: Model validation, refinement, and extension. Blacksburg, VA: Virginia Polytechnic Institute and State University.

Neal, J. D., \& Sirgy, M. J. (2004). Measuring the effect of tourism services on travelers' quality of life: Further validation. Social Indicators Research, 69(3), 243-277.

Opperman, M. (1995). Travel life cycle. Annals of Tourism Research, 22(3), 535-552.

Pine, B. J., I. I., \& Gilmore, J. H. (1999). The experience economy: Work is theatre \& every business a stage. Boston: Harvard Business School Press.

Schor, J. (1991). The overworked American: The unexpected decline of leisure. New York: Basic Books.

Schor, J. (1998). The overspent American: Why we want what we don't need. New York: Harper Collins.

Seligman, M. (1990). Learned optimism: How to change your mind and your life. New York: Vintage Books.

Seligman, M., Steen, T. A., Park, N., \& Peterson, C. (2005). Positive psychology progress. American Psychologist, 60(5), 410-421.

Sheldon, K. M., \& Lyubomirksy, S. (2006). Achieving sustainable gains in happiness: Change your actions, not your circumstances. Journal of Happiness Studies, 7(1), 55-86.

Sirgy, M. J., Kruger, S. P., Lee, D.-J., \& Yu, G. B. (2010). How does a travel trip affect tourists' life satisfaction? Journal of Travel Research. doi:10.1177/0047287510362784.

Spiers, A., \& Walker, G. J. (2009). The effects of ethnicity and leisure satisfaction on happiness, peacefulness, and quality of life. Leisure Sciences, 31(1), 84-99.

Strauss-Blasche, G., Ekmekcioglu, C., \& Marktl, W. (2000). Does vacation enable recuperation? Changes in well-being associated with time away from work. Occupational Medicine, 50(3), 167-172.

Swinyard, W. R., Kau, A.-K., \& Phua, H.-Y. (2001). Happiness, materialism, and religious experience in the US and Singapore. Journal of Happiness Studies, 2(1), 13-32.

Tugade, M. M., \& Fredrickson, B. L. (2007). Regulation of positive emotions: Emotion regulation strategies that promote resilience. Journal of Happiness Studies, 8(3), 311-333.

UNWTO. (1995). Technical manual no2: Collection of tourism expenditure statistics: World Tourism Organization.

UNWTO. (2008). Tourism market trends 2006. World overview and tourism topics (No. 2006 ed.). Madrid: UNWTO

Veenhoven, R. (1984). Conditions of happiness. Dordrecht, The Netherlands: Kluwer.

Veenhoven, R. (1994). Is happiness a trait? Tests of the theory that a better society does not make people any happier. Social Indicators Research, 32(2), 101-160. 
Veenhoven, R. (2010). Capability and happiness: Conceptual differences and reality links. Journal of SocioEconomics, 39(3), 344-350.

Vingerhoets, A. J. J. M., Sanders, N., \& Kuper, W. (1997). Health issues in international tourism: The role of health behavior, stress and adaptation. In M. V. Tilburg \& A. J. J. M. Vingerhoets (Eds.), Psychological aspects of geographical moves: Homesickness and acculturation stress (pp. 197-211). Amsterdam: Amsterdam Academic Archive.

Vingerhoets, A. J. J. M., Van Huijgevoort, M., \& Van Heck, G. L. (2002). Leisure sickness: A pilot study on its prevalence, phenomenology, and background. Psychotherapy and Psychosomatics, 71(6), 311-317.

Watson, D., Clark, L. A., \& Tellegen, A. (1988). Development and validation of brief measures of positive and negative affect: The PANAS scales. Journal of Personality and Social Psychology, 54(6), 1063-1070.

Westman, M., \& Eden, D. (1997). Effects of a respite from work on burnout: Vacation relief and fade-out. Journal of Applied Psychology, 82(4), 516-527.

Westman, M., \& Etzion, D. (2001). The impact of vacation and job stress on burnout and absenteeism. Psychology and Health, 16(5), 595-606. 